\title{
Pengaruh Pupuk Majemuk Tablet pada Pertumbuhan Bibit Kakao (Theobroma cacao L.)
}

\section{(The Effect of Tablete Compound Fertilizer on Cocoa [Theobroma cacao L.] Seedlings Growth)}

\author{
Rinanda Anggeraini ${ }^{1)}$, Bambang Utoyo ${ }^{2)^{*}}$, Wiwik Indrawati ${ }^{2)}$ \\ ${ }^{1)}$ Program Studi Produksi dan Manajemen Industri Perkebunan Politeknik Negeri Lampung dan ${ }^{2)}$ \\ Jurusan Budidaya Tanaman Perkebunan Politeknik Negeri Lampung, Jl. Soekarno-Hatta No. 10 \\ Rajabasa, Bandar Lampung, 35144 \\ E-mail: utoyo1962@polinela.ac.id
}

\begin{abstract}
Cocoa (Theobroma cacao L.) is one of the estate crop commodities that is currently being developed because the cocoa plant is one of the export commodities that produce a lot of foreign exchange and has a role as high value sector besides oil and gas. Cocoa farming can increase the income of cocoa farmers, create and expand employment. This experiment used Randomized Block Design (RBD) which consisted of 4 treatments that was repeated 6 times (control, 1 tablet.polybag ${ }^{-1}, 2$ tablet.polybag ${ }^{-1}, 3$ tablet.polybag ${ }^{-1}$ ). This study was conducted to determine the best rate of compound fertilizer tablets for cocoa seedlings growth. The data obtained were analyzed by analysis of variance at 95\% accuracy level. The results showed that there was a compound effect on the growth of cocoa seedlings to the variable of seed height, stem diameter, leaf number, leaf area, dry root weight, and total dry weight of stalk. Application of tablet compound fertilizer 1 tablet.polybag ${ }^{-1}$ gives the best results on the growth of cocoa seedlings.
\end{abstract}

Keywords: cocoa seedlings growth, inorganic fertilizer, tablet compound fertilizer

Diterima: 10 November 2016 / Disetujui: 5 Maret 2017 / Diterbitkan: 3 Mei 2017

\section{PENDAHULUAN}

Prospek agribisnis kakao di Indonesia cukup bagus karena potensi lahan produksi yang luas. Melalui program peningkatan kualitas sumberdaya petani kakao serta didukung dengan hasil inovasi teknologi pemupukan dan hormon alami, pengelolaan hama, dan penyakit terpadu, serta semua sistem budidaya lainnya yang didasarkan pada semangat ramah lingkungan akan meningkatkan kuantitas dan kualitas produksi kakao dengan tetap menjaga kelestarian lingkungan.

Tanaman kakao (Theobroma cacao L.) merupakan salah satu komoditas ekspor yang mampu memberikan kontribusi dalam upaya peningkatan devisa Indonesia. Komoditas kakao menempati peringkat ke tiga ekspor sektor perkebunan dalam menyumbang devisa negara, setelah komoditas karet dan minyak sawit mentah (CPO). Ekspor komoditas kakao Provinsi Lampung periode Mei 2010 melonjak hingga 427,60\% dibandingkan dengan ekspor April 2010. Kenaikan ini merupakan yang terbesar dari 10 golongan barang ekspor pada periode tersebut. Kenaikan kakao 
ini juga menyumbang 9,56\% terhadap total ekspor Lampung yang mencapai 199,19 juta dolar AS (Badan Pusat Statistik, 2010).

Menurut BBP2TP Ambon (2013) kakao merupakan salah satu komoditi unggulan, baik untuk memenuhi kebutuhan dalam negeri maupun kebutuhan ekspor, serta memiliki prospek yang cukup cerah pada era globalisasi persaingan pasar bebas, yang tujuannya untuk meningkatkan pendapatan devisa Negara.

Faktor pendukung pertumbuhan kakao adalah tersedianya bibit yang berkualitas dan mampu beradaptasi pada kondisi lingkungan lapangan.Untuk meningkatkan produksi tanaman kakao, pemilihan bibit merupakan langkah pertama yang harus diperhatikan. Pembibitan merupakan salah satu tahap penting dalam pertumbuhan tanaman kakao yang akan berpengaruh bagi pertumbuhan dan produksi tanaman dilapangan. Pada saat ini penyediaan bibit menjadi suatu permasalahan penting, bukan saja dari segi kuantitasnya tetapi juga dari daya produksinya. Untuk memperoleh bibit yang sehat dan baik perlu mendapatkan perlakuan khusus selama dalam pembibitan. Dalam rangka peningkatan produksi, pelaksanaan pembibitan perlu mendapat perhatian serius karena pertumbuhan bibit akan turut mendukung penentuan keberhasilan penanaman di lapangan, bibit merupakan titik awal dari hasil akhir yang diharapkan.

Banyak faktor yang mempengaruhi pertumbuhan bibit kakao selama dalam pembibitan yaitu media tanam yang sesuai dan tepat serta kegiatan pemupukan. Pemupukan merupakan upaya dalam penambahan unsur hara yang dibutuhkan bibit kakao dengan menggunakan pupuk anorganik maupun pupuk organik. Penggunaan pupuk anorganik dalam jangka panjang dapat menyebabkan kemunduran sifat-sifat fisik, kimia, dan biologi tanah (Zulkarnain, 2010).

Pupuk anorganik atau pupuk buatan adalah jenis pupuk yang dibuat oleh pabrik dengan cara meramu berbagai bahan kimia sehingga memiliki prosentase kandungan hara yang tinggi. Menurut jenis unsur hara yang dikandungnya, pupuk anorganik dapat dibagi menjadi dua yakni pupuk tunggal dan pupuk majemuk. Pada pupuk tunggal, jenis unsur hara yang dikandungnya hanya satu macam. Biasanya berupa unsur hara makro primer, misalnya urea hanya mengandung unsur nitrogen. Pupuk majemuk adalah pupuk yang mengandung lebih dari satu jenis unsur hara. Namun pada kenyataannya, petani hanya menggunakan pupuk tunggal, seperti urea sumber $\mathrm{N}$, SP36 sumber P, dan KCL untuk sumber K yang pemberiannya dilakukan secara sendiri-sendiri. Keuntungan dari pupuk jenis ini adalah bahwa dalam satuan berat pupuk dapat diperoleh lebih dari satu unsur hara, sehingga biaya per satuan hara pupuk dan biaya pemupukan di lapang lebih rendah daripada pupuk tunggal. Kelemahannya adalah kadar tiap unsur tidak selalu tepat dengan kebutuhan tanaman. Pada satu kasus dengan dosis tertentu, unsur hara tertentu berlebih, sedangkan unsur hara lainnya kurang (Setiawan, 2006). Oleh karena itu, penelitian ini bertujuan untuk menganalisis pengaruh pemberiaan pupuk majemuk tablet pada pertumbuhan bibit kakao. 


\section{METODE PENELITIAN}

Percobaan ini dilakukan di kebun Politeknik Negeri Lampung pada Oktober 2015 sampai dengan Maret 2016. Alat yang digunakan dalam percobaan ini adalah cangkul, golok, gembor, ayakan, baskom, hand sprayer, ember plastik, gunting stek, tampah, meteran, paranet, penggaris, papan, jangka sorong, gelas ukur, oven, spektrofotometer, flamefotometer dan alat tulis untuk mencatat data. Bahan yang digunakan dalam percobaan ini adalah benih kakao klon TSH 858, top soil, pupuk majemuk tablet, air, bambu, tali plastik, polibeg hitam ukuran $20 \mathrm{~cm}$ x $30 \mathrm{~cm}$, dan Dithane M-45.

Penelitian ini menggunakan metode Rancangan Acak Kelompok (RAK). Proses penelitian ini dimulai pendederan, pemindahan kecambah ke polibeg kemudian pupuk majemuk tablet diaplikasikan terhadap pertumbuhan kakao.

$\mathrm{P}_{0} \quad=$ Kontrol (tanpa pemberian pupuk)

$\mathrm{P}_{1} \quad=$ Dosis 1 tablet.bibit ${ }^{-1}$

$\mathrm{P}_{2} \quad=$ Dosis 2 tablet.bibit ${ }^{-1}$

$\mathrm{P}_{3} \quad=$ Dosis 3 tablet.bibit ${ }^{-1}$

Dari perlakuan tersebut diperoleh 4 satuan percobaan dan di ulang 6 kali, masing- masing perlakuan dibuat setiap satuan percobaan terdiri dari 3 bibit tanaman kakao sehingga secara keseluruhan terdapat 72 polibeg.

Pengamatan tanaman meliputi: tinggi tanaman, diameter tanaman, jumlah daun, luas daun, dan berat kering akar dan berat kering brangkasan total. Pengamatan dilakukan setiap 2 minggu yang dimulai pada 4 MST sampai 16 MST.

\section{Pengujian pH dan kandungan unsur hara (N, P, K) di dalam tanah}

Topsoil yang akan digunakan sebagai media diuji derajat keasaman tanah $(\mathrm{pH})$ dan unsur hara N, P, K di Laboratorium Analisis Kimia Politeknik Negeri Lampung. Pengukuran hara N dan $\mathrm{P}$ menggunakan alat spektrofotometer, sedangkan untuk analisis unsur hara $\mathrm{K}$ menggunakan alat flamefotometer. Pengujian tanah dilakukan $2 \mathrm{x}$ yaitu saat awal (sebelum perlakuan) dan akhir penelitian (setelah penelitian).

\section{Tinggi bibit (cm)}

Tinggi bibit diukur dari pangkal batang sampai titik tumbuh dengan menggunakan penggaris, pengukuran dilakukan saat bibit umur 4 MST sampai 16 MST dengan interval 2 minggu sekali.

\section{Diameter batang (cm)}

Diameter batang diukur $2 \mathrm{~cm}$ dari permukaan tanah, dengan menggunakan jangka sorong. Pengamatan dilakukan saat bibit umur 4 MST sampai 16 MST dengan interval 2 minggu sekali. 


\section{Jumlah daun (helai)}

Jumlah daun yang dihitung adalah daun yang telah membuka sempurna dengan ciri-ciri helaian daun dalam posisi terbuka yang ditandai telah terlihatnya tulang-tulang daun seluruhnya bila diamati dari atas daun. Pengamatan yang dilakukan saat bibit umur 4 MST sampai 16 MST dengan interval 2 minggu sekali.

\section{Luas daun $\left(\mathrm{cm}^{2}\right)$}

Pengukuran total luas daun dilakukan pada umur bibit 16 MST. Daun yang diukur adalah daun yang telah membuka sempurna. Pengukuran luas daun bibit kakao dilakukan dengan cara mengukur panjang helaian daun kakao, kemudian lebar daun. Dengan mengambil 1 tanaman sampel dari tiap plot. Dengan rumus:

LD = Panjang $x$ Lebar $x$ Konstanta (0,68) (Nasaruddin, 2010 dalam Ermansyah, 2012)

\section{Berat kering akar $(\mathrm{g})$}

Bobot kering akar dilakukan dengan cara membersihkan akar tanaman dari tanah. Selanjutnya dikering anginkan yang sebelumnya dilakukan pencacahan terlebih dahulu dan dimasukkan kedalam amplop serta diberi label. Kemudian dimasukkan kedalam oven pada suhu $60^{\circ} \mathrm{C}$ selama 48 jam hingga diperoleh berat tetap. Menimbang berat kering akar menggunakan neraca ohaus. Pengamatan dilakukan saat bibit umur 16 MST.

\section{Berat brangkasan kering total (g)}

Berat brangkasan kering total ditentukan dengan cara membersihkan tanaman dari tanah dan dipisahkan antara bagian akar dan brangkasannya. Selanjutnya dikeringanginkan yang sebelumnya dilakukan pencacahan terlebih dahulu untuk mempermudah pengeringan dan dimasukkan kedalam amplop serta diberi label. Kemudian dimasukkan ke dalam oven pada suhu $60{ }^{\circ} \mathrm{C}$ selama 48 jam hingga diperoleh berat tetap. Terakhir melakukan penimbangan menggunakan neraca ohaus. Pengamatan dilakukan saat bibit umur 16 MST.

\section{HASIL DAN PEMBAHASAN}

\section{Pengaruh Pupuk Majemuk Tablet terhadap Sifat Kimia Tanah pada Awal dan Akhir Percobaan}

Berdasarkan analisis tanah yang dilakukan pada awal dan akhir percobaan yang terdiri atas keasaman tanah $(\mathrm{pH})$ dan unsur hara N, P, K. Dalam budidaya tanaman, keberadaan pupuk merupakan faktor yang sangat penting untuk menunjang optimalisasi produksi yang telah ditetapkan. Namun, upaya memupuk yang dilakukan secara sembarangan dan tidak terukur justru dapat merugikan tanaman itu sendiri, bahkan tidak sedikit tanaman yang mengalami kematian akibat cara memupuk yang kurang tepat (Jedeng, 2011).

4 Jurnal AIP Volume 5 No. 1| Mei 2017: 1-14 
Tabel 1. Beberapa sifat kimia tanah pada awal percobaan

\begin{tabular}{lcccc}
\hline \multirow{2}{*}{ Sifat kimia } & $\mathrm{pH}$ & $\mathrm{N}$ total & P tersedia & K-dd \\
\cline { 3 - 5 } & & $\%$ & $\mathrm{ppm}$ & $\mathrm{me} .100 \mathrm{~g}^{-1}$ \\
\hline Nilai & 5,35 & 0,06 & 10,14 & 0,20 \\
\hline
\end{tabular}

Tabel 2. Beberapa sifat kimia tanah pada akhir percobaan

\begin{tabular}{|c|c|c|c|c|}
\hline \multirow{2}{*}{ Perlakuan } & \multirow{2}{*}{$\mathrm{pH}$} & $\mathrm{N}$ total & $\mathrm{P}$ tersedia & K-dd \\
\hline & & $\%$ & $\mathrm{ppm}$ & me. $100 \mathrm{~g}^{-1}$ \\
\hline $\mathrm{P}_{0}$ (kontrol) & 5,29 & 0,07 & 14,66 & 0,89 \\
\hline $\mathrm{P}_{1}\left(1\right.$ tablet.polibeg $\left.{ }^{-1}\right)$ & 4,73 & 0,09 & 26,27 & 1,04 \\
\hline $\mathrm{P}_{2}\left(2\right.$ tablet.polibeg $\left.{ }^{-1}\right)$ & 4,80 & 0,12 & 25,64 & 1,13 \\
\hline $\mathrm{P}_{3}\left(3\right.$ tablet.polibeg $\left.{ }^{-1}\right)$ & 4,44 & 0,14 & 26,59 & 1,16 \\
\hline
\end{tabular}

Tabel 1 dan 2 menunjukan tanah awal dan akhir terjadi sedikit penurunan $\mathrm{pH}$. Menurut Rosmarkam dan Yuwono (2002) bahwa tanah yang di dalamnya terdapat akar tanaman sering menyebabkan turunnya $\mathrm{pH}$ walaupun dalam skala kecil. Penurunan $\mathrm{pH}$ disebabkan oleh akar tanaman yang melakukan proses pernafasan mengeluarkan gas $\mathrm{CO}_{2}$. Makin banyak akar (baik volume maupun panjang akar), maka makin tinggi kecenderungan penurunan $\mathrm{pH}$.

Pemberian pupuk N, P, K pada tanaman sangat memberikan pengaruh pada pertumbuhan tanaman. Menurut Saribun (2008) bahwa pemberian pupuk NPK terhadap tanah dapat berpengaruh baik pada kandungan hara tanah dan dapat berpengaruh baik bagi pertumbuhan tanaman karena unsur hara makro yang terdapat dalam unsur $\mathrm{N}, \mathrm{P}, \mathrm{K}$ diperlukan bagi pertumbuhan dan perkembangan tanaman.

Menurut Winarso (2005), peningkatan pemberian pupuk N akan meningkatkan serapan unsur hara $\mathrm{P}$ di dalam tanah, hal ini disebabkan bila pertumbuhan baik maka akan meningkatkan serapan hara lainnya akan baik pula, terlihat dari pertumbuhan akar yang baik akan memperluas jangkauan serapan hara bagi tanaman. Bila tanaman kekurangan $\mathrm{N}$ maka tanaman menjadi kerdil, tanaman cepat masak hal ini berhubungan dengan fungsi P yang mempercepat pematangan buah. Begitu pula Syafruddin (2006) menyatakan bahwa kelebihan unsur hara nitrogen dapat meningkatkan kerusakan akibat serangan hama dan penyakit, dan tanaman lebih mudah rebah. Sedangkan kekurangan nitrogen tidak dapat memenuhi kebutuhan tanaman untuk mencapai tingkat produksi yang optimal. Hal ini didukung pernyataan Buckman dan Brady (1982) bahwa hara $\mathrm{N}$ bersifat racun bagi tanaman apabila diberikan terlalu banyak. 
Menurut Lingga (2001) bahwa unsur nitrogen (N) sangat penting untuk pertumbuhan vegetatif tanaman karena dapat merangsang pertumbuhan secara keseluruhan, khususnya batang, cabang dan daun, ketersediaan unsur nitrogen adalah penting pada saat pertumbuhan tanaman, karena nitrogen berperan dalam seluruh proses biokimia tanaman. Sedangkan fosfor $(\mathrm{P})$ berperan untuk pembentukan sejumlah protein tertentu, berperan dalam fotosintesis dan respirasi sehingga sangat penting untuk pertumbuhan tanaman keseluruhan, selain itu berperan penting memperbaiki sistem perakaran tanaman. Hal ini sesuai dengan pernyataan Soepardi (1983) yang menyatakan bahwa besar kecilnya serapan P tanaman tergantung dari ketersediaan P dalam larutan tanah karena unsur hara banyak diserap melalui akar.

Unsur hara $\mathrm{N}$ dan $\mathrm{P}$ merupakan unsur hara yang sangat mobil dalam jaringan tanaman sehingga bila kekurangan hara tersebut maka akan segera ditranslokasikan pada bagian tanaman yang muda. Peranan unsur hara $\mathrm{N}$ dan $\mathrm{P}$ pada masa vegetatif seimbang tetapi ketika memasuki masa generatif maka peranan $\mathrm{P}$ lebih dominan karena $\mathrm{P}$ sangat diperlukan dalam proses pembentukan bunga, buah dan biji (Novriani, 2010). Unsur hara P bahwa curah hujan juga menjadi faktor penentu dalam penyediaan hara $\mathrm{P}$ bagi tanaman jagung. Daerah yang curah hujan rendah pada tanah muda biasanya mengandung P lebih tinggi. Sejalan dengan ini tanaman jagung juga akan tumbuh baik pada daerah yang mempunyai curah hujan rendah. Dengan menciptakan kondisi yang sesuai bagi tanaman jagung, maka diharapkan kebutuhan hara $\mathrm{P}$ untuk meningkatkan produksi dan kualitas hasil (Winarso, 2005).

Meningkatnya analisa tanah pada perlakuan kontrol pada $\mathrm{P}$ tersedia saat akhir penelitian diduga terdapat cacing tanah yang hidup di tanah karena kotoran cacing tanah terkandung bahan organik yang lebih tinggi sehingga dapat meningkatkan $\mathrm{P}$ tersedia didalam tanah. Begitu pula meningkatnya unsur hara $\mathrm{K}$ dalam perlakuan kontrol pada akhir penelitian dibandingkan analisa awal karena proses kimia unsur dalam tanah umumnya cenderung berubah dari bentuk yang kompleks menjadi bentuk sederhana yaitu lambat laun menjadi keadaan tersedia (Buckman dan Brady, 1982). Hasil analisis kandungan $\mathrm{K}$ pada Tabel 1 dan 2 menunjukkan bahwa semakin banyak pemberian pupuk majemuk maka semakin tinggi unsur hara K. Beberapa hasil penelitian mendukung hasil penelitian ini yaitu pemupukan $\mathrm{K}$ mampu meningkatkan pertumbuhan dibandingkan dengan kontrol pada tanaman rosemary (Singh dkk., 2007). Kalium dapat diserap tanaman melebihi kebutuhannya tanpa meracuni tanaman (Ismunadji, 1989 dalam Ruhnayat, 2007).

\section{Pengaruh Pupuk Majemuk Tablet pada Pertumbuhan Tinggi Bibit}

Berdasarkan data tinggi tanaman pada Tabel 3 terlihat pemberian pupuk majemuk tablet menunjukkan perbedaan antarperlakuan. Perlakuan 1 tablet.polibeg ${ }^{-1}, 2$ tablet.polibeg ${ }^{-1}$ dan 3 tablet.polibeg ${ }^{-1}$ memberikan pengaruh nyata pada pertumbuhan kakao dibandingkan kontrol (tanpa perlakuan). Sedangkan perlakuan 1 tablet.polibeg ${ }^{-1}$ menunjukkan hasil yang tertinggi, walaupun 
antara perlakuan 1 tablet.polibeg ${ }^{-1}$ dengan 2 tablet.polibeg ${ }^{-1}$ tidak berbeda nyata. Menurut Lingga (1996) bahwa tersedianya unsur hara N, P, K dalam jumlah yang cukup dan seimbang membuat organ - organ tanaman bisa dan mampu untuk tumbuh dan berkembang lebih sempurna hal ini akan dapat menunjang produksi yang diinginkan. Menurut Mas'ud (1992), jika suplai nitrogen cukup, daun tanaman akan tumbuh besar dan memperluas permukaan yang tersedia untuk fotosintesis sehingga laju fotosintesis yang meningkat akan menghasilkan fotosintat dalam jumlah banyak sehingga mampu meningkatkan tinggi tanaman.

Tabel 3. Nilai rerata pengaruh pupuk majemuk tablet pada pertumbuhan tinggi bibit kakao

\begin{tabular}{|c|c|}
\hline Perlakuan & Tinggi tanaman $(\mathrm{cm})$ \\
\hline $\mathrm{P}_{0}$ (kontrol) & $26,85 \mathrm{c}$ \\
\hline $\mathrm{P}_{1}\left(1\right.$ tablet.polibeg $\left.^{-1}\right)$ & $32,07 \mathrm{a}$ \\
\hline $\mathrm{P}_{2}\left(2\right.$ tablet.polibeg $\left.{ }^{-1}\right)$ & $31,14 a b$ \\
\hline $\mathrm{P}_{3}\left(3\right.$ tablet.polibeg $\left.{ }^{-1}\right)$ & $29,49 \mathrm{~b}$ \\
\hline
\end{tabular}

$\overline{\text { Keterangan: Nilai rata-rata yang diikuti oleh huruf yang sama pada kolom yang sama menunjukkan }}$ tidak berbeda nyata dengan uji BNT pada taraf 5\%

Menurut Simarmata (2004), salah satu unsur hara kalium yang sangat berperan dalam memacu pertumbuhan tinggi tanaman. Apabila tanaman mengalami kekurangan unsur kalium, maka tanaman akan tumbuh lebih pendek, sehingga tanaman menjadi kerdil dan mudah rebah. Pada perlakuan 3 tablet.polibeg ${ }^{-1}$ menunjukkan hasil yang belum optimal dibandingkan dengan perlakuan 1 tablet.polibeg ${ }^{-1}$ dan 2 tablet.polibeg ${ }^{-1}$. Hal tersebut diduga perlakuan 3 tablet.polibeg ${ }^{-1}$ kelebihan hara menyebabkan ketidakseimbangan sehingga tanaman tidak bisa lagi memberikan pengaruh terhadap pertumbuhan bibit secara optimal, bahkan dapat menyebabkan toksik bagi tanaman itu sendiri.

Menurut Hekl dkk. (1972) dalam Rosmarkam dan Yuwono (2002), pemupukan nitrogen yang tinggi menyebabkan penurunan kualitas tanaman karena menurunkan kadar karbohidrat. Kelebihan unsur hara bagi tanaman juga tidak mempunyai kebaikan apapun akan tetapi malah dapat mengganggu pertumbuhan tanaman, yaitu diduga dapat menimbulkan suatu gejala pada tanaman sepeti keracunan unsur hara yang biasa terjadi yaitu tanaman keracunan unsur hara mikro seperti Aluminium, Seng, Fe, dan Mn. Keracunan ini terjadi karena pengaruh dari kondisi tanah yang terlalu asam (Rukmana, 2005).

\section{Pengaruh Pupuk Majemuk Tablet pada Pertumbuhan Diameter Batang}

Berdasarkan data diameter batang pada Tabel 4 terlihat bahwa pemberian pupuk majemuk tablet menunjukkan perbedaan antarperlakuan. Perlakuan 1 tablet.polibeg ${ }^{-1}, 2$ tablet.polibeg $^{-1}$, dan 3 tablet.polibeg $^{-1}$ memberikan pengaruh nyata pada pertumbuhan kakao dibandingkan dengan 
perlakuan kontrol. Pada pertumbuhan diameter batang, perlakuan 2 tablet.polibeg ${ }^{-1}$ memberikan hasil tertinggi walaupun tidak ada perbedaan dengan perlakuan 1 tablet.polibeg ${ }^{-1}$.

Tabel 4. Nilai rerata pengaruh pupuk majemuk tablet pada pertumbuhan diameter batang kakao

\begin{tabular}{|c|c|}
\hline Perlakuan & Diameter batang $(\mathrm{mm})$ \\
\hline $\mathrm{P}_{0}$ (kontrol) & $0,61 \mathrm{c}$ \\
\hline $\mathrm{P}_{1}\left(1\right.$ tablet.polibeg $\left.^{-1}\right)$ & $0,72 \mathrm{a}$ \\
\hline $\mathrm{P}_{2}\left(2\right.$ tablet.polibeg $\left.{ }^{-1}\right)$ & $0,73 \mathrm{a}$ \\
\hline $\mathrm{P}_{3}\left(3\right.$ tablet.polibeg $\left.{ }^{-1}\right)$ & $0,68 \mathrm{~b}$ \\
\hline
\end{tabular}

Keterangan: Nilai rata-rata yang diikuti oleh huruf yang sama pada kolom yang sama menunjukkan tidak berbeda nyata dengan uji BNT pada taraf 5\%

Unsur hara K dapat meningkatkan kekuatan batang (Soepardi, 1983). Hal ini sesuai dengan (Zaubin, 1996) bahwa kandungan kalium yang meningkat di dalam tanaman akan menambah daya tahan tanaman terhadap penyakit karena dinding sel tanaman semakin tebal. Kekurangan unsur hara $\mathrm{K}$ dapat menyebabkan melemahnya batang sehingga tanaman mudah rebah dan terserang penyakit (Ismunadji, 1989 dalam Ruhnayat, 2007). Hal ini sesuai dengan pendapat Dwijoseputro (1983) bahwa tanaman akan tumbuh subur apabila semua unsur hara yang dibutuhkan tanaman berada dalam jumlah yang cukup serta berada dalam bentuk yang bisa diabsorbsi.

\section{Pengaruh Pupuk Majemuk Tablet pada Pertumbuhan Jumlah Daun}

Berdasarkan data jumlah daun pada Tabel 5, terlihat bahwa pemberian pupuk majemuk tablet menunjukkan perbedaan antarperlakuan. Pada perlakuan 1 tablet.polibeg ${ }^{-1}, 2$ tablet.polibeg ${ }^{-1}$ dan 3 tablet.polibeg ${ }^{-1}$ memberikan pengaruh nyata pada pertumbuhan kakao dibandingkan dengan perlakuan kontrol (tanpa perlakuan). Sedangkan perlakuan 1 tablet.polibeg ${ }^{-1}$ menunjukkan hasil yang tertinggi, walaupun antara perlakuan 1 tablet.polibeg ${ }^{-1}$ dengan 2 tablet.polibeg ${ }^{-1}$ tidak berbeda nyata.

Tabel 5. Nilai rerata pengaruh pupuk majemuk tablet pada jumlah daun kakao

\begin{tabular}{lc}
\hline \multicolumn{1}{c}{ Perlakuan } & Jumlah daun (helai) \\
\hline $\mathrm{P}_{0}$ (kontrol) & $13,76 \mathrm{c}$ \\
$\mathrm{P}_{1}\left(1\right.$ tablet.polibeg $\left.^{-1}\right)$ & $16,78 \mathrm{a}$ \\
$\mathrm{P}_{2}\left(2\right.$ tablet.polibeg $\left.^{-1}\right)$ & $16,67 \mathrm{a}$ \\
$\mathrm{P}_{3}(3$ tablet.polibeg & -1 \\
\hline
\end{tabular}

Keterangan: Nilai rata-rata yang diikuti oleh huruf yang sama pada kolom yang sama menunjukkan tidak berbeda nyata dengan uji BNT pada taraf 5\% 
Menurut Onggo (2001), jumlah daun tanaman merupakan komponen yang dapat menunjukkan pertumbuhan tanaman. Pembentukan daun sendiri sebetulnya dipengaruhi oleh sifat genetik tanaman, namun lingkungan yang baik dapat mempercepat pembentukkan tersebut. Lingga dan Marsono (1996) bahwa unsur hara nitrogen bagi tanaman adalah untuk merangsang pertumbuhan vegetatif khususnya batang, cabang dan daun.

Perlakuan 3 tablet.polibeg ${ }^{-1}$ mempunyai jumlah daun lebih rendah dibandingkan 1 tablet.polibeg $^{-1}$ dan 2 tablet.polibeg $^{-1}$ diduga ketidakseimbangan hara, menyebabkan perakaran terhambat sehingga mempengaruhi fotosintat yang digunakan untuk membentuk daun baru. Menurut Prawiranata dkk. (1991), pemberian pupuk yang tidak tepat jumlah tidak memberikan pertumbuhan dan perkembangan yang optimal. Pemberian $\mathrm{N}$ yang tinggi menyebabkan tanaman mudah rebah karena sistem perakaran relatif menjadi lebih sempit (Marschner, 1986 dalam Rosmarkam dan Yuwono, 2002).

\section{Pengaruh Pupuk Majemuk Tablet pada Luas Daun}

Berdasarkan data luas daun pada Tabel 6, terlihat bahwa pemberian pupuk majemuk tablet menunjukkan perbedaan antarperlakuan. Perlakuan 1 tablet.polibeg $^{-1}, 2$ tablet.polibeg ${ }^{-1}$, dan 3 tablet.polibeg $^{-1}$ memberikan pengaruh nyata pada pertumbuhan kakao dibandingkan dengan perlakuan kontrol (tanpa perlakuan). Sedangkan perlakuan 1 tablet.polibeg $^{-1}$ menunjukkan hasil yang tertinggi, walaupun antara perlakuan 1 tablet.polibeg ${ }^{-1}$ dan 2 tablet.polibeg ${ }^{-1}$ tidak berbeda nyata dengan 3 tablet.polibeg ${ }^{-1}$.

Tabel 6. Nilai rerata pengaruh pupuk majemuk tablet pada pertumbuhan luas daun kakao

\begin{tabular}{lc}
\hline \multicolumn{1}{c}{ Perlakuan } & Luas daun $\left(\mathrm{cm}^{2}\right)$ \\
\hline $\mathrm{P}_{0}$ (kontrol) & $138,80 \mathrm{~b}$ \\
$\mathrm{P}_{1}(1$ tablet.polibeg \\
\end{tabular}

Keterangan: Nilai rata-rata yang diikuti oleh huruf yang sama pada kolom yang sama menunjukkan tidak berbeda nyata dengan uji BNT pada taraf 5\%

Menurut Lukikariati dkk. (1996) dalam Yoseva dkk. (2013), luas daun yang besar meningkatkan laju fotosintesis tanaman sehingga akumulasi fotosintat yang dihasilkan menjadi tinggi. Fotosintat yang dihasilkan akan mempercepat pertumbuhan dan perkembangan bagian pembentukan tanaman seperti daun, batang, dan akar. Heliyanto dkk. (1986) menyatakan bahwa pada tanaman tembakau, semakin tinggi dosis $\mathrm{N}$ semakin mempengaruhi panjang dan lebar daun produksi. Tanaman membutuhkan unsur $\mathrm{N}$ untuk melakukan proses-proses metabolisme, terutama pada masa vegetatif. 
Menurut Dewi Hs dan Tambingsila (2014), luas daun menggambarkan kemampuan tanaman untuk melakukan fotosintesis hal ini disebabkan karena fotosintesis terjadi di daun sehingga semakin luas daun maka semakin tinggi laju fotosintesis sehingga berat kering yang dihasilkan semakin tinggi.

\section{Pengaruh Pupuk Majemuk Tablet pada Bobot Kering Akar}

Berdasarkan data hasil berat kering akar tanaman pada Tabel 7, terlihat bahwa pemberian pupuk majemuk tablet menunjukkan perbedaan antar perlakuan. Pada perlakuan 1 tablet.polibeg ${ }^{-1}$,

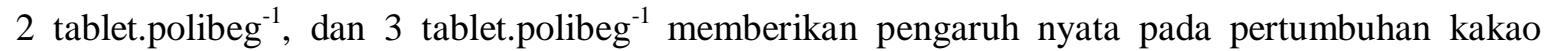
dibandingkan dengan perlakuan kontrol (tanpa perlakuan). Hal ini berkaitan unsur hara di dalam tanah yang didapatkan lebih baik. Perlakuan 1 tablet.polibeg $^{-1}$ memberikan hasil tertinggi, walaupun antara perlakuan 1 tablet.polibeg ${ }^{-1}$ dan 2 tablet.polibeg ${ }^{-1}$ tidak berbeda nyata, tetapi berbeda nyata dengan 3 tablet.polibeg ${ }^{-1}$.

Tabel 7. Nilai rerata pengaruh pupuk majemuk tablet pada bobot kering akar kakao

\begin{tabular}{lc}
\hline \multicolumn{1}{c}{ Perlakuan } & Berat kering akar \\
\hline $\mathrm{P}_{0}($ kontrol $)$ & $3.97 \mathrm{c}$ \\
$\mathrm{P}_{1}\left(1\right.$ tablet.polibeg $\left.^{-1}\right)$ & $5.20 \mathrm{a}$ \\
$\mathrm{P}_{2}\left(2\right.$ tablet.polibeg $\left.^{-1}\right)$ & $5.07 \mathrm{a}$ \\
$\mathrm{P}_{3}(3$ tablet.polibeg \\
\end{tabular}

Keterangan: Nilai rata-rata yang diikuti oleh huruf yang sama pada kolom yang sama menunjukkan tidak berbeda nyata dengan uji BNT pada taraf 5\%

Hal ini diduga apabila faktor lingkungan seperti cahaya sebagai sumber energi dalam proses fotosintesis menunjukan unsur hara yang diserap oleh akar berjalan secara optimal. Maka fotosintat yang dihasilkan akan banyak yang digunakan untuk pertumbuhan bagian tanaman lainnya. Menurut Sarief (1986) dalam Yoseva dkk. (2013), perakaran tanaman berkembang dengan baik dan pertumbuhan bagian-bagian tanaman lainnya akan baik pula. Karena akar mampu menyerap air dan unsur hara yang dibutuhkan tanaman.

Lakitan (1996) menyatakan bahwa berat kering tanaman merupakan cerminan dari kemampuan tanaman tersebut dalam menyerap unsur hara yang ada. Jika kemampuan tanaman dalam menyerap unsur hara lebih tinggi, maka hasil fotosintat akan berjalan dengan baik sehingga organ tanaman dapat menjalankan fungsinya dengan baik. Selain faktor unsur hara yang diserap oleh tanaman diduga juga bahwa jumlah akar yang terbentuk akan mempengaruhi terhadap berat kering akar. Akar yang terbentuk juga berhubungan erat dengan pengaruh lingkungan khususnya kondisi tanah yang memungkinkan pertumbuhan akar menjadi baik dan jumlahnya lebih banyak. 
Hal ini menunjukkan bahwa Meningkatnya bobot kering akar karena unsur hara $\mathrm{K}$ dapat membantu penyerapan unsur hara untuk tanaman (Gaol dkk., 2014).

\section{Pengaruh Pupuk Majemuk Tablet pada Bobot Kering Total Brangkasan}

Berdasarkan data rataan hasil berat kering total brangkasan pada Tabel 8, terlihat bahwa pemberian pupuk majemuk tablet menunjukkan perbedaan antarperlakuan. Pada perlakuan 1 tablet.polibeg $^{-1}$, 2 tablet.polibeg ${ }^{-1}$, dan 3 tablet.polibeg ${ }^{-1}$ memberikan pengaruh nyata pada pertumbuhan kakao dibandingkan dengan perlakuan kontrol (tanpa perlakuan). Hal ini berkaitan unsur hara di dalam tanah yang didapatkan lebih baik. Perlakuan 1 tablet.polibeg ${ }^{-1}$ memberikan hasil tertinggi, walaupun antara perlakuan 1 tablet.polibeg ${ }^{-1}$ dan 2 tablet.polibeg ${ }^{-1}$ tidak berbeda nyata. Hal ini diduga semakin banyak tanaman menyerap unsur hara secara optimal maka semakin baik pertumbuhan tanaman dan dapat meningkatkan berat tanaman.

Tabel 8. Nilai rerata pengaruh pupuk majemuk tablet pada bobot kering total brangkasan

\begin{tabular}{|c|c|}
\hline Perlakuan & Total brangkasan $(\mathrm{g})$ \\
\hline $\mathrm{P}_{0}$ (kontrol) & $11,70 \mathrm{c}$ \\
\hline $\mathrm{P}_{1}\left(1\right.$ tablet.polibeg $\left.{ }^{-1}\right)$ & $15,75 \mathrm{a}$ \\
\hline $\mathrm{P}_{2}\left(2\right.$ tablet.polibeg $\left.{ }^{-1}\right)$ & 15,18 a \\
\hline $\mathrm{P}_{3}\left(3\right.$ tablet.polibeg $\left.{ }^{-1}\right)$ & $14,12 \mathrm{~b}$ \\
\hline
\end{tabular}

Keterangan: Nilai rata-rata yang diikuti oleh huruf yang sama pada kolom yang sama menunjukkan tidak berbeda nyata dengan uji BNT pada taraf 5\%.

Menurut Agrifina (2006) dalam Aji (2013) bahwa berat kering tanaman dianggap sebagai indikator pertumbuhan tanaman, sebab pada dasarnya berat kering tanaman ini merupakan hasil akumulasi bersih selama tanaman hidup. Buckman dan Brady (1982) dalam Supramudho (2008) yaitu pada nitrogen berfungsi untuk memperbesar ukuran daun dan meningkatkan prosentase protein. Ukuran daun yang besar dan protein yang banyak akan meningkatkan berat kering tanaman. Hasil ini sesuai dengan pernyataan Dewi Hs \& Tambingsila (2014) bahwa penambahan bobot kering total diakibatkan oleh serapan unsur hara $\mathrm{N}$.

Perlakuan 3 tablet.polibeg ${ }^{-1}$ memberikan hasil yang belum optimal dibandingkan perlakuan 1 tablet.polibeg ${ }^{-1}$, dan 2 tablet.polibeg ${ }^{-1}$ diduga unsur hara yang terlalu berlebihan sehingga mempengaruhi pertumbuhan fisiologis tanaman menyebabkan pertumbuhan terhambat. Hal ini sesuai dengan pernyataan Lubis (2008) yang menyatakan pemberian pupuk pada bibit sangat jelas memberikan pengaruh terhadap pertumbuhan namun jika pemberian berlebihan akan berpengaruh menekan pertumbuhan. 


\section{KESIMPULAN DAN SARAN}

\section{Kesimpulan}

Pemberian pupuk majemuk tablet dapat meningkatkan pertumbuhan bibit kakao terhadap 6 parameter pengamatan yaitu pada tinggi bibit, diameter batang, jumlah daun, luas daun, bobot kering akar, dan bobot kering total brangkasan. Aplikasi pemberian pupuk majemuk tablet pada dosis 1 tablet.polibeg ${ }^{-1}$ memberikan pertumbuhan bibit kakao yang terbaik dengan nilai masingmasing parameter tinggi bibit sebesar 32,07 cm, diameter batang sebesar 0,72 mm, jumlah daun sebesar 16,78 helai, luas daun sebesar 161,68 $\mathrm{cm}^{2}$, bobot kering akar sebesar 5,20 g, dan bobot kering total brangkasan sebesar $15,75 \mathrm{~g}$.

\section{Saran}

Saran yang dapat diberikan berdasarkan hasil penelitian ini adalah perlu dilakukan penelitian lanjutan dengan waktu yang lebih lama untuk melihat bagaimana efektivitas pupuk majemuk tablet pada umur tanaman antara 4-5 bulan sesuai dosis dan perlakuan.

\section{DAFTAR PUSTAKA}

Aji, S. (2013). Pengaruh Penyimpanan Biji dan Pemberian Ekstrak Rebung (Dendrocalamus asper Backer) terhadap Pertumbuhan Bibit Kakao (Theobroma cacao L.) pada Media Gambut. UIN Suska Riau.

Badan Pusat Statistik. (2010). Statistik Indonesia Tahun 2010. Retrieved August 1, 2016, from https://www.bps.go.id/.

BBP2TP Ambon. (2013). Media Pembibitan Kakao. Retrieved October 1, 2015, from http://ditjenbun.deptan.go.id.

Buckman \& Brady. (1982). Ilmu Tanah. Jakarta: Bhrata Karya Aksara.

Dewi Hs, E.S. \& Tambingsila, M. (2014). Kajian peningkatan serapan NPK pada pertumbuhan dan hasil tanaman jagung dengan pemberian kombinasi pupuk anorganik majemuk dan berbagai pupuk organik. Jurnal Ilmiah AgroPet, 11(1), 46-57.

Dwijoseputro, D. (1983). Pengantar Fisiologi Tumbuhan. Jakarta: PT Gramedia.

Ermansyah. (2012). Pemanfaatan Mikoriza Vesicular Arbuskula (MVA) dan Berbagai Jenis Kompos terhadap Pertumbuhan Bibit Sambung Pucuk Tanaman Kakao (Theobroma cacao L.). Universitas Hasanuddin.

Gaol, S. K. L., Hamidah, H., \& Gantar, S. (2014). Pemberian zeolit dan pupuk kalium untuk meningkatkan ketersediaan hara $\mathrm{K}$ dan pertumbuhan kedelai di Entisol. Jurnal Online Agroekoteknologi, 2(3), 1151-1159.

Heliyanto. B., Rachman, A., \& Murdiyati, A. S. (1988). Pengaruh dosis pupuk N dan P terhadap produksi dan mutu tembakau Madura pada tanah mediteran. Penelitian Tanaman Tembakau dan Serat, 13(1-2), 32-39. 
Hindersah, R. \& Simarmata, T. (2012). Potensi rizobakteri Azotobacter dalam meningkatkan kesehatan tanah. Jurnal Natur Indonesia, 5(2), 127-133.

Jedeng, I. W. (2011). Pengaruh dan Jenis Pupuk Organik terhadap Pertumbuhan Tanaman Seledri. Universitas Udayana.

Lakitan, B. (1996). Fisiologi Pertumbuhan dan Perkembangan Tanaman. Jakarta: PT Raja Grafindo Persada.

Lingga, P dan Marsono. (1996). Petunjuk Penggunaan Pupuk. Jakarta: Penebar Swadaya.

Lingga, P. (2001). Petunjuk Penggunaan Pupuk. Jakarta: Penebar Swadaya.

Lubis, A. U. (2008). Kelapa Sawit (Elaeis guineensis Jacq.) di Indonesia. Edisi 2. Medan: Pusat Penelitian Kelapa Sawit.

Mas'ud, (1992). Telaah Kesuburan Tanah. Yogyakarta: Penerbit Angkasa.

Novriani. (2010). Alternatif pengelolaan unsur hara P (fosfor) pada budidaya jagung. AgronobiS, $2(3), 42-49$.

Onggo, T. W. (2001). Pertumbuhan dan hasil tanaman tomat pada aplikasi berbagai formula dan dosis pupuk majemuk lengkap. Universitas Padjadjaran.

Prawiranata, W. (1991). Dasar-dasar Fisiologi Tumbuhan Jilid III. Bogor: Institut Pertanian Bogor.

Rosmarkam, A dan Yuwono, N. (2002). Ilmu Kesuburan Tanah. Yogyakarta: Kanisius.

Ruhnayat, A. (2007). Penentuan kebutuhan pokok unsur hara N, P, K mntuk pertumbuhan tanaman panili (Vanilla planifolia Andrews). Buletin Penelitian Tanaman Rempah dan Obat, 18(1), 49-59.

Rukmana, R. (2005). Jeruk Besar Potensi dan Prospeknya. Yogyakarta: Kanisius.

Saribun. (2008). Pengaruh pupuk majemuk NPK pada berbagai dosis terhadap pH, P potensial dan P tersedia serta hasil (Brassicajuncea) pada Fluventic Eutrudepts Jatinangor. Universitas Padjadjaran.

Setiawan, R. A. (2006). Keefektifan pupuk majemuk lepas terkendali Pasir Maung Fertilizer $(P M F)$ pada bibit kelapa sawit (Elaeis guineensis Jacq.) pada tanah Ultisol dari Jasinga. Institut Pertanian Bogor.

Singh, M., Ganesha Rao, R. S., \& Ramesh, S. (2007). Effects of N and K on growth, herbage, oil yield and nutrient uptake patterns in rosemary (Rosmarinus officinalis L.) under semi-arid tropical conditions. The Journal of Horticultural Science and Biotechnology, 82(3), 414-419.

Soepardi, G. (1983). Sifat dan Ciri Tanah. Bogor: Institut Pertanian Bogor.

Supramudho, N. G. (2008). Efisiensi Serapan N serta Hasil Tanaman Padi (Oryza sativa L.) pada Berbagai Imbangan Pupuk Kandang Puyuh dan Pupuk Anorganik di Lahan Sawah Palur Sukoharjo. Universitas Sebelas Maret.

Winarso, S. (2005). Kesuburan Tanah Dasar-dasar Kesehatan dan Kualitas Tanah. Yogyakarta: Gava Media. 
Yoseva, S., Ardian, \& Mariana, C. (2013). Pemanfaatan Kompos Kulit Buah Kakao pada Pertumbuhan Bibit Kakao Hibrida (Theobroma cacao L.). Universitas Riau.

Zaubin, R. (1996). Beberapa aspek pemupukan yang berpengaruh terhadap produktifitas dan kesehatan tanaman lada. In Makalah Seminar. Balai Penelitian Tanaman Rempah dan Obat (Vol. 11).

Zulkarnain. (2010). Dasar-dasar Hortikultura. Jakarta: PT Bumi Aksara. 